\title{
GRS河川堤防の耐越流侵食性向上 \\ に対する堤体材料の効果 \\ EFFECTS OF LEVEE MATERIALS ON RESISTANCE AGAINST OVERFLOW EROSION FOR GRS LEVEE
}

\author{
森田麻友 ${ }^{1} \cdot$ 倉上由貴 ${ }^{2} \cdot$ 二瓶泰雄 ${ }^{3} \cdot$ 板倉舞 $^{1}$ \\ 吉森佑介 ${ }^{1} \cdot$ 浅野友里 $^{4} \cdot$ 二見捷 ${ }^{4}$ \\ Mayu MORITA, Yuki KURAKAMI, Yasuo NIHEI, Mai ITAKURA, Yusuke YOSHIMORI \\ Yuri ASANO and Sho FUTAMI

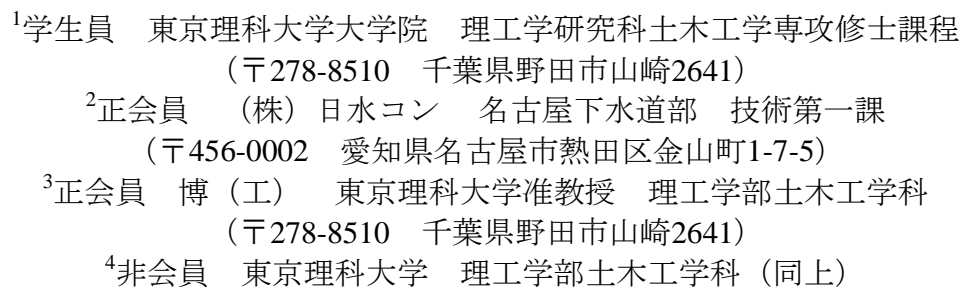

Recent extreme flood affected huge flood disaster with a large number of levee breaches which were mainly caused by overflow erosion. For increasing the resistance of levee to overflow erosion with attention to fine fraction of levee materials, we examine the resistance of armored and GRS (Geosynthetic-Reinforced Soil) levees. Various laboratory tests were conducted to evaluate the resistance of this method to overflow erosion. The results indicated that 1) the resistance of armored and GRS levees have high resistance against overflow erosion with the increase of fine fraction of levee materials mainly due to low permeability and high cohesion of fine sediment and 2) the GRS levee with fine sediment maintained the height of the levee during a longer duration than that with sand.

Key Words: river levee, geotextile, fine sediment, overflow, erosion

\section{1. 序論}

2013 年は，50年に一度の大雨に対する特別大雨洪水警 報やそれ相当の豪雨が全国各地で発生した。特に，同年 7 月 28 日に発生した山口・島根豪雨災害 ${ }^{1)}$ では, 山口県 内の阿武川等で超過洪水が発生し, 土堤のみならず三面 コンクリート張りの堤防も多くが越流決壊した. そもそ も河川堤防の設計では，計画高水位を上回る超過洪水の 越流侵食は考慮されていないため 2)，3，上記の決壊が生 じるものと考えられる. また決壊要因として浸透や表の り尻の洗堀よりも越流が多くを占めるとの報告もある ${ }^{4)}$. 今後, 地球温暖化に伴う豪雨の発生頻度が増えることが 予想され ${ }^{5}$, 超過洪水に伴う越流時にも粘り強く壊れず, 汇濫水量を最小化するために, 十分な而越流侵食性を有 する河川堤防強化技術の開発が望まれている.

一般的な而越水堤防としては，三面コンクリート張り のアーマ・レビー（以下，従来形式堤防）と高規格堤防 (スーパー堤防) がある. アーマ・レビーは，一定の耐
越流侵食性を有しているものの，過去の洪水・津波災害 1)，。見られるように，堤体をカバーするコンクリート 製被覆工が流出し決壊に至る事例が見られるなど十分な 而越流侵食性を有しているとは言えない，一方，高規格 堤防は，膨大な用地とそれに伴うコスト面での負担が非 常に大きい. そのため，低コスト・省スペースで高い耐 越流侵食性を有する堤防強化技術が必要となる。

このような堤防強化技術として，著者らは，堤体と被 覆工を一体化して被覆工の流出を抑制するために, 鉄道 や道路盛土で一般に使われるジオシンセティック補強土

（GRS，Geosynthetic-Reinforced Soil）と堤体表面の被覆工を 繋げた新形式河川堤防（GRS 河川堤防）を提案し，高い 而越流侵食性を有していることを室内実験において示し

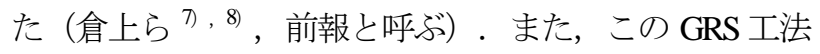
は防潮堤の而越流侵食性強化技術としての有効性も示さ れている ${ }^{9)}$. GRS工法自体は, 元々, 急勾配ののり面を 有する盛土においても高い耐震性を有することが知られ ており ${ }^{10)}$ ，GRS 河川堤防は洪水（津波）と地震の複 


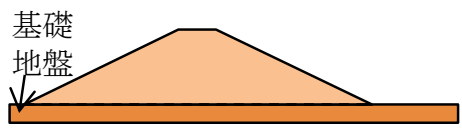

(a) 土堤

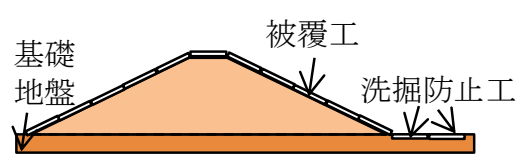

(b) 従来形式堤防

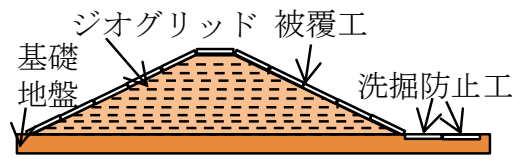

(c) 新形式堤防

図-1 様々な補強条件における河川堤防の模式図

合対策になり得るものと期待される. このように GRS 河 川堤防・防潮堤の耐越流侵食性に関する基本的な有効性 は検証されているものの，幅広い実験条件下での検証は 今後の課題であり, 様々な条件下 (越流状況や堤体材料・ 勾配，ジオグリッド（ジオテキスタイルの一つ）の種類 など）における検証実験を行う必要がある.

本研究では，堤体材料に着目し，GRS 河川堤防の而越 流侵食性に対する堤体材料の影響を把握するために，小 型開水路を用いた室内実験を行う。ここでは，前報にお いて用いられた堤体材料が砂のみであったことから, 細 粒分含有率を変化させた条件を設定する. また，堤方の 補強条件としては, 土堤, 従来形式堤防, 新形式堤防 (図 -1）の3 種類を設定し, 各補強条件と堤体材料の関係も 合わせて検討する.これらの条件下における「越流実験」 を行う. それに加えて, 様々な堤体材料条件下における

「浸透実験」も行い，堤体材料による浸透状況の変化を 把握すると共に，これらと越流実験結果から得られる決 壊状況の関連性を検証する.

\section{2. 室内実験方法}

\section{（1）越流実験の概要}

越流実験の方法は，前報と同じである，すなおち，図 -2 に示す水平小型開水路 (全長 $5.0 \mathrm{~m}$, 幅 $0.2 \mathrm{~m}$, 高さ $0.35 \mathrm{~m}$ ) の中央部に模型堤防を設置し，上流部より一定流量を流 した. 本水路のある実験室には地下にタンクが設置され, それを介して複数の水路で水を循環しているため, 細粒 分を含む堤体が侵食・流出すると, 濁水の影響が他の水 路にも残る，そこで細粒分を含む堤体の実験時のみ，下 流タンクに污水用ポンプを設置し，適宜排水して木製水 槽に濁水を貯める.

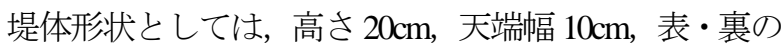
り面勾配を 2 割（1:2）とし，この堤体を基礎地盤（高さ $5 \mathrm{~cm})$ の上に設置した。この条件は，前報と同じであり，

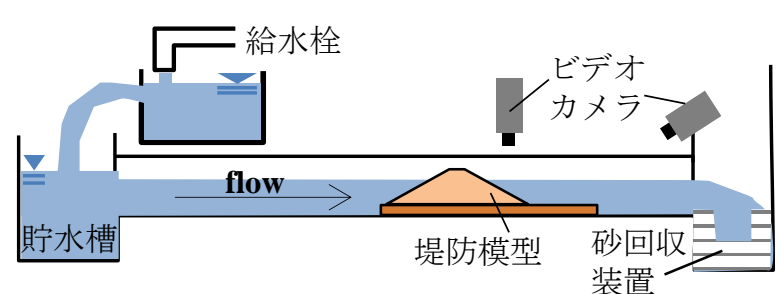

図-2 越流実験で用いられた小型水平開水路

表-1 越流実験の条件

\begin{tabular}{|c|c|c|c|}
\hline 分類 & $\begin{array}{l}\text { 細粒分 } \\
\text { 含有率 } \\
F c[\%]\end{array}$ & $\begin{array}{c}\text { 締固め度 } \\
D c[\%]\end{array}$ & 補強条件 \\
\hline \multirow{4}{*}{ 土堤 } & 0 & 85 & \multirow{4}{*}{ 無し } \\
\hline & 10 & 85 & \\
\hline & 20 & 87 & \\
\hline & 30 & 85 & \\
\hline \multirow{3}{*}{$\begin{array}{l}\text { 従来 } \\
\text { 形式 }\end{array}$} & 0 & 85 & \multirow{3}{*}{ 被覆工のみ } \\
\hline & 10 & 85 & \\
\hline & 20 & 87 & \\
\hline \multirow{2}{*}{$\begin{array}{c}\text { 新 } \\
\text { 形式 }\end{array}$} & 0 & 85 & \multirow{2}{*}{$\begin{array}{c}\text { 被覆工十 } \\
\text { ジオグリッド }\end{array}$} \\
\hline & $\frac{10}{20}$ & 87 & \\
\hline
\end{tabular}

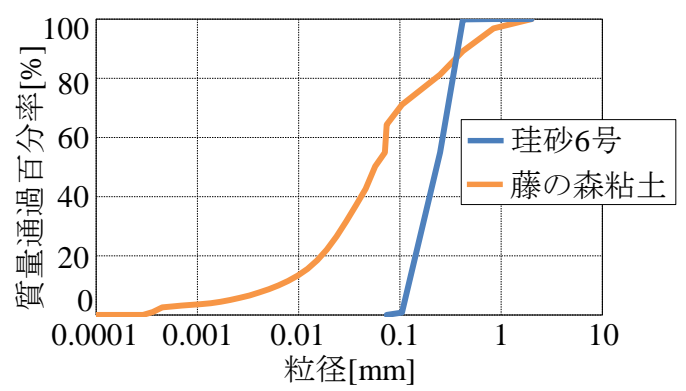

図-3 堤体材料の粒径分布

縮尺 $1 / 25$ を想定している（堤防高さの実スケール $: 5 \mathrm{~m}$ ). フルードの相似則を仮定すると，例えば実物と模型にお ける力の比は縮尺の 3 乗となる. 実験条件としては，表 -1 に示すように，堤体材料のうち $0.075 \mathrm{~mm}$ 以下の細粒分 含有率 Fc を $0 \%$ （砂のみ），10\%，20\%，30\%とした。 この際，砂には豊浦砂加硅砂 6 号，細粒分としては藤の 森粘土をそれぞれ用いており，それらの粒径分布を図-3 に例示する. 表中の締固め度 $D_{c}$ は，JS A 1210 の標準プ ロクターに基づいて与えており，ここでは $85 \%$ か $87 \%$ と した. また, 補強条件としては, 土堤, 従来形式堤防, 新形式堤防とした. ここで，土堤のみ 4 ケースの Fcにつ いて実施し, 従来・新形式堤防は 3 ケースの Fc とする. 新形式堤防の構造や作り方は前報と同じである. 越流条 件としては，流量 $Q=5.61 \times 10^{-3}\left[\mathrm{~m}^{3} / \mathrm{s}\right]$ とするが，土堤の $F c=$ $20 \%$ ケースのみ, 実験当時の装置の都合で $Q=3.21 \times 10^{-3}\left[\mathrm{~m}^{3} / \mathrm{s}\right]$ とやや小さめの值で実施した.

\section{（2）浸透実験の概要}

前述した越流実験における従来形式堤防と新形式堤防 の破堤には，裏のり面における被覆工の挙動が重要であ り，それには，堤体表面の越流状況のみならず，堤体内 


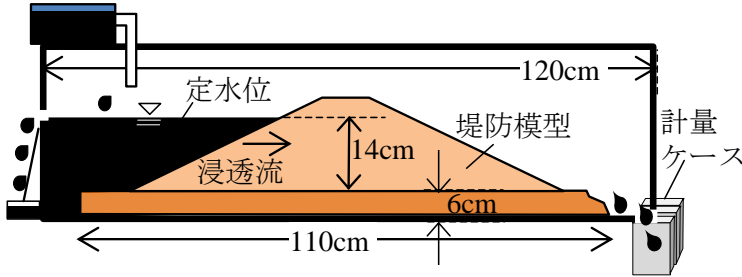

図-4＼cjkstart浸透実験の概要

部における浸透状況も大きく関与しているものと推察さ れる. そこで, 前節の越流実験とは別に, 堤外地からの 河川水の浸透実験を行う，浸透実験では，図-4に示寸よ うに，長さ $120 \mathrm{~cm}$ ，奥行き幅 $45 \mathrm{~cm}$ ，高さ $45 \mathrm{~cm}$ の水槽を用 いる. 水槽内には，越流実験と同じ寸法の堤防を基礎地 盤（長さ $110 \mathrm{~cm}$, 高さ $6 \mathrm{~cm})$ 上に設置している. 水槽の奥 行き幅が広いため, 適宜仕切りを設けて奥行き幅を狭め ている，そのため，浸透実験条件としては，越流実験と 同じく堤体材料の細粒分含有率 $F c$ を $0 ， 10,20 ， 30 \%$ の 4 ケースとした. 用いる堤体材料としては, 越流実験時 と同様である.

実験では水槽内に模型堤防を作成し，堤外地の水を墨 汁で着色し，その堤外地側の水位を一定值 $(=14 \mathrm{~cm})$ に保 って堤防内の浸透挙動を側面と上面からビデオカメラ (HDR-XR550V，SONY製) やインターバルカメラ（Time Lapse Camera TLC200，(株バイコム製）を用いて連続 的に撮影した. また裏のり尻下流側に計量ケースを設け, 浸透流量や土砂侵食量の横断分布を計測した.

\section{3. 結果と考察}

\section{（1）様々な細粒分含有率での土堤の侵食特性}

様々な細粒分含有率を有する堤防の耐越流侵食性に対 する細粒分の影響を明らかにするため, 細粒分含有率 F を 0\%（砂のみ），10\%，20\%，30\%と変化させた時の土 堤の越流侵食形状を図-5に示寸。ここでは側面からの撮 影画像から得られた結果を表示寸る。まず， $F c=0 \%$ （砂 のみ）では，越流開始直後から裏のり面全体や背後の基 礎地盤全体が侵食され，概ね裏のり面と平行に侵食され ている7). 次に, $F c=10 \%$ のースでは, $F_{c}=0 \%$ と類似し て裏のり面と平行に侵食が進むものの， $F c=0 \%$ のきよ りも侵食の進む速度が遅くなっており, $t=100$ でもわずか に堤体面積を有していることが分かる．さらに，Fc=20\% の場合では，これまでの 2 ケースとは大きく異なり，裏 のり面側で侵食が始まるものの，その侵食面は元の裏の り面とは平行にはなっておらず，また，基礎地盤の侵食 は進んでいない，この裏のり面側の侵食は，局所的に進 行する部分があることや切り立っている部分が見られ， 粘性土の河岸侵食 ${ }^{11)}$ と類似している. また，上面からの 撮影画像から， $F_{C}=0 \%$ （砂のみ）や10\%のケースでは侵食 形状に横断方向の差異は観察されなかったが，この

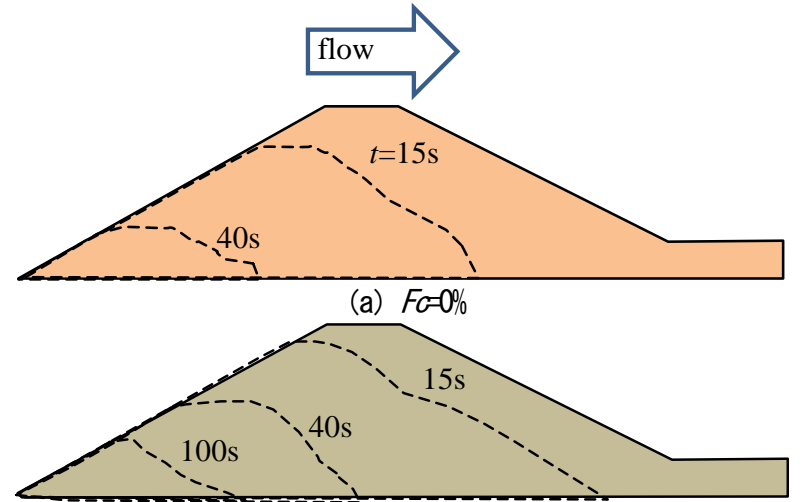

(b) $F G=10 \%$

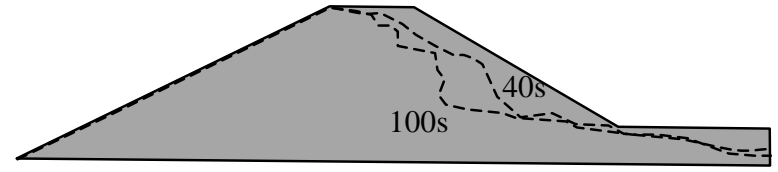

(c) $F c=20 \%$

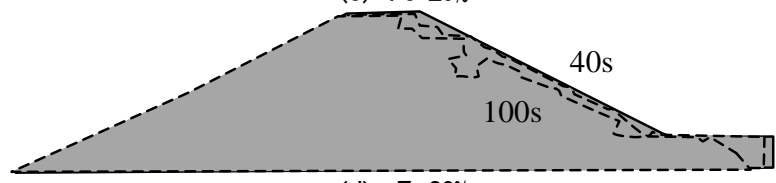

(d) $F G=30 \%$

図-5 土堤における越流侵食形状

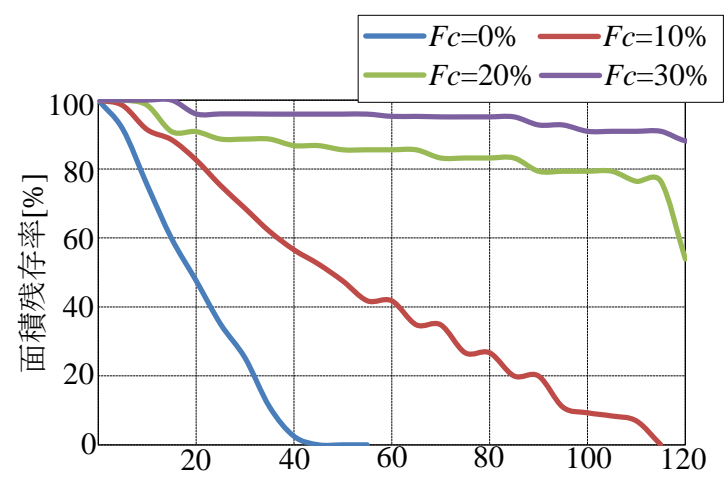

越流からの経過時間[s]

図一 6 土堤の堤体面積残存率

$F c=20 \%$ ケースでは侵食パターンの横断方向変化が生じ ており，側面よりも侵食している所も見られた。こちら も細粒分を多く含む粘性土の特徽と言える ${ }^{12)}$. さらに, $F c=30 \%$ 場合には，裏のり面での侵食が極端に少なくな っており，実験時間の範囲ではわずかに裏のり面が侵食 されるに留まっている.このケースにおいても横断方向 の侵食形状の変化は著しく $t=120$ 降ではより顕著とな っていた.

これらのことを定量的に比較・検討寸るために，堤体 の面積残存率の時間変化を図-6に示寸．ここで，面積残 存率とは，時々刻々の堤体断面積を初期断面積で割った ものである.ここでは，Fc=30\%のケースで横断方向の侵 食形状変化が顕在化する $120 \mathrm{~s}$ までの結果を表示している. これより, 細粒分含有率が大きくなると面積残存率の傾 きは緩やかになっており，侵食されにくくなっているこ とが確認できる．このように，堤体材料の細粒分含有率 


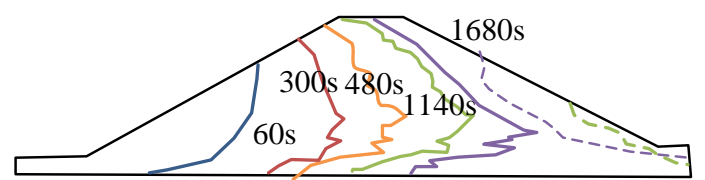

(a) $F_{G}=0 \%$

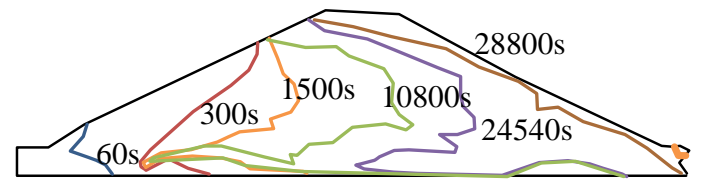

(b) $F c=10 \%$

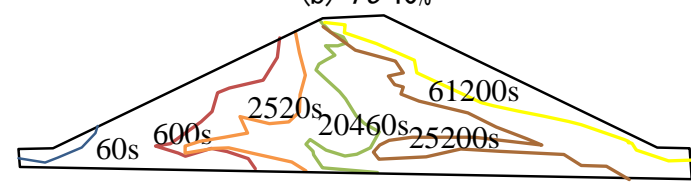

(c) $F_{C}=20 \%$

図-7 浸透実験における堤体内の浸透 - 侵食形状（実線：墨 汁の浸透面, 点線 : 裏のり面の侵食形状)

を大きくすると，土堤の耐越流侵食性が向上しているこ とが分かる．この要因として，細粒分の割合が増加する と，堤体への浸透能が低下寸るとともに，単一粒径の場 合と比べて砂の移動限界掃流力が増加寸るためである. なお，今回は，実験装置の都合により $F c=20 \%$ 土堤の越 流侵食実験の際のみ流量が小さい状態で行った。今後は 他の実験ケースと同じ流量の元， $F=20 \%$ の土堤の越流侵 食実験を再度行う必要があると考えられる。また，細粒 分を含む実験の場合には水路横断面にて侵食形状が異な るため，侵食形状の横断方向変化を把握すべきである.

\section{（2）土堤における浸透特性}

土堤内における浸透状況の基本特性を把握するために, 細粒分含有率 $F c$ が 0，10，20\%における墨汁の浸透面の 時間変化を図-7 に示寸．図中には，裏のり面の侵食形状 も点線で表示している．まず，砂のみの $F c=0 \% の$ 場合に は，浸透流が表のり面から裏のり面に進み，裏のり尻の 方向に向かっている，そのため，浸透面はいずれのケー スも表のり面と平行な初期状態から直立，その逆の傾き へと変化し, 堤体の底面付近の浸透流速が大きい. また, 裏のり面では，浸透流の到達による侵食が発生しており $(t=1140 \mathrm{~s})$ ，その後，侵食量は拡大し，墨汁の浸透面と ほぼ繋がっている（t=1680s）。次に，Fc=10\%では，墨汁 の浸透面の形状や進行の様子は， $F c=0 \%$ のースと大局 的には類似寸る. しかしながら，浸透面の進行速度は非 常に遅く, 墨汁の浸透面が裏のり尻に到達するのは約 28800s であり，Fc=0\%のケースよりも 1 オーダー以上大き い. 同様に, $F c=20 \%$ に関しても, $F_{c}=10 \%$ と類似しており, こちらも裏のり尻への到達時間は 60000s を越えている. また， $F c=0 \%$ ケースでは，墨汁の浸透面が裏のり面に 現れて侵食が生じたが, $F c=10 \% や 20 \%$ のースでは裏の り面に浸潤面は見られず，浸透流はいずれも裏のり尻下

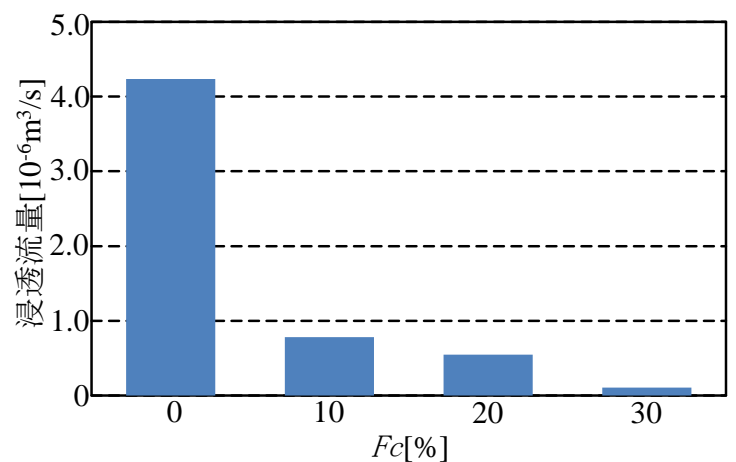

図-8 裏のり尻部における浸透流量（浸透実験，定常時）

の基礎地盤から流出していることが確認された。 なお， $F c=30 \%$ では実験終了時まで墨汁の浸潤面には大きな変 化が見られなかった．ただし，このときの浸透状況は横 断方向変化が顕著であり, 裏のり尻からは浸透流の流出 は小さいものの観測されていた（図面省略）。

これらの浸透流特性を定量的に比較するために，裏の り尻部の浸透流量を図-8 に示す。ここでは，各実験にお ける定常時の流量を表示する. これより, 細粒分含有率 が大きくなると定常時の浸透流量は大きく減少する. $F c=10,20 ， 30 \%$ 各流量と $F_{c}=0 \%$ の流量の比は，割合表 示をすると，それぞれ 18.4，12.9，2.51\%となる．今回の 実験では堤体材料以外は変えていないので，この浸透流 量の比は，そのまま見かけの透水係数の比率に相当する. その場合， $F c=0 \%$ の透水係数は，予備的に行った変水位 試験より $1.70 \times 10^{4} \mathrm{~m} / \mathrm{s}$ であったので， $F c=10 ， 20 \%$ の場合 の透水係数は $1.0 \times 10^{-5} \mathrm{~m} / \mathrm{s}$ のオーダー, $F c=30 \%$ の場合は $1.0 \times 10^{-6} \mathrm{~m} / \mathrm{s}$ のオーダーになる. なお，次節で示寸従来・ 新形式堤防の浸透性は, 被覆工やジオグリッドの存在に より，土堤の場合とは詳細には異なる部分があり，今後 検討を行う予定である.

\section{（3）従来形式及び新形式堤防の越流侵食特性}

\section{1)細粒分による耐越流侵食性向上効果}

細粒分の違いによる新形式堤防の越流侵食特性を把握 するために，細粒分含有率 $F c=0 ， 10 ， 20 \%$ の時の越流侵 食形状を図-9 に示す. 図中の点線は, ジオグリッドに相 当寸る. これより， $F_{c}=0 \%$ では，裏のり面の被覆工と堤 体間の隙間や洗掘工下部が侵食されると, 裏のり面の被 覆工がわずかに変位し，被覆工の段差（不陸）が生じる

（その様子は $=1225 \mathrm{~s}$ で見られる）。このような隙間が起 きるとそこに流れが集中し，かつ不陸の部分には砂の吸 出し，侵食が顕在化するため，短時間で堤体の侵食が進 む. 一方， $F c=10 \%$ では，不陸や堤体と被覆工間の隙間が 生じるまでの時間も長くなると共に（図中の $t=5660 \mathrm{~s}$ ）, その後, 決壊に至るまでの時間も大きく伸びており，長 時間の越流に対して粘り強く壊れにくいものとなってい ることが分かる．これは，隙間や不陸部分からの堤体材 


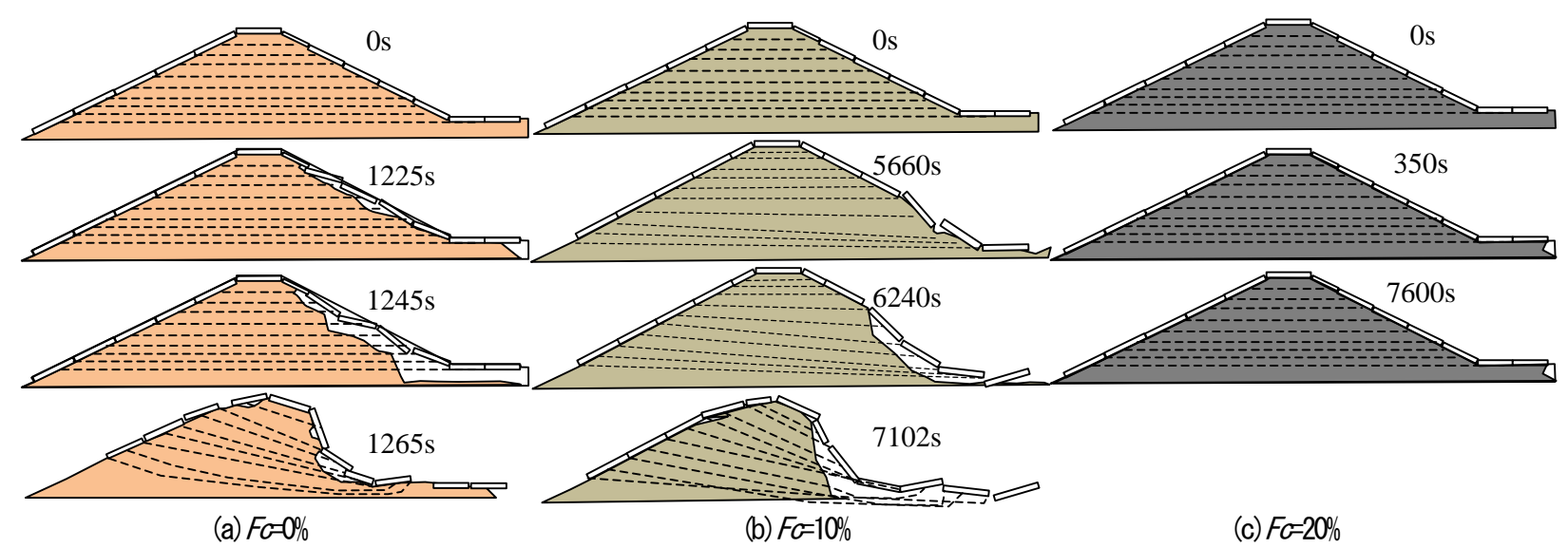

図-9 新形式堤防の越流侵食形状

料の吸出しが大幅に減少すると共に，そこでの侵食も砂 のみの $F c=0 \%$ と比べて小さい. さらに, $F c=20 \%$ の場合で は，洗掘工下部の下流端でわずかに洗掘が起こるが，そ の後，堤体の侵食は全く見られなかった.

これらのことを従来形式も含めて定量的に検討寸るた めに， $F c=0 ， 10 ， 20 \%$ における従来・新形式堤防の面積 残存率の時間変化を図-10に示寸，ここで， $F c=0 \%$ の結果 は前報の結果と同じものである.まず，従来形式堤防の 結果に着目寸ると, $F c=0 \%$ の時には, $t=540$ s 頃に完全に破 堤しているが, $F c=10 \%$ の時には, 破堤時間が $t=2880 \mathrm{~s}$ まで 延びている. さらに，Fc=20\%の時には面積残存率が減り 始めるのが $t=5990$ かからとなっており，細粒分含有率を大 きくすると，従来形式の越流侵食開始時間や完全破堤時 間が大幅に伸びることが分かる．本実験条件では，既存 の調査結果 ${ }^{4}$ とフルードの相似則より，600s が想定決壊 時間となっている．これと比べると，細粒分を $10 \%$ にす ると，この条件を十分クリアできている.

一方，新形式堤防の場合には， $F c=0 \%$ 時には $t=1355 \mathrm{~s}$ 頃に完全に破堤しており，この時点でも想定決壊時間を 越えている，細粒分含有率を増や寸と，従来形式堤防と 同様に而越流侵食性は向上し，Fc=10\%のケースでは完全 破堤するまでに $た 7155 \mathrm{~s}$ 間も越流侵食に耐えている.ささら に, $F c=20 \%$ の時には実験時間内 (2 時間半) では, 全く 侵食されず，面積残存率は 100\%を維持していた. なお， このケースでは, さらに実験を継続する必要があったが, 装置の関係で越流実験を中断したことに注意されたい.

これらを含む全ての実験ケースにおける堤体の欠損時 間を図-11に示寸.ここでの久損時間としては，堤体の面 積残存率が $85 \%$ を下回る時間とする。 これより，土堤で は前述のように細粒分と共に破堤時間が漸増している一 方, 従来形式堤防では $F c=10,20 \%$ の結果は $F c=0 \%$ よりも 1 オーダー増えている.さらに新形式堤防では， $F c=10 \%$ の破損時間は $F c=0 \%$ よりも 1 オーダー増え， $F c=20 \%$ の ときには越流開始から 2 時間半を越えてもほとんど侵食 されず，破堤に至らなかったため図中にはのと図示して

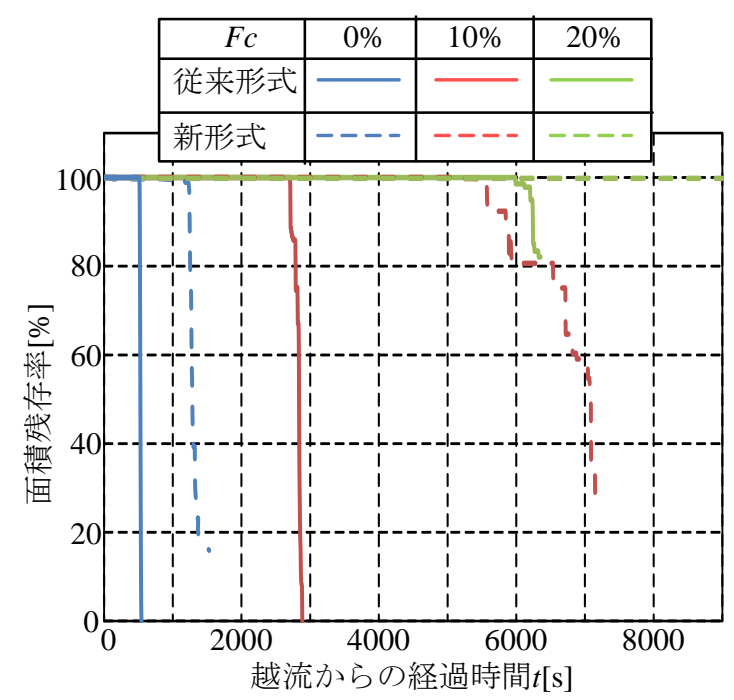

図-10 従来・新形式堤防における面積残存率の時間変化

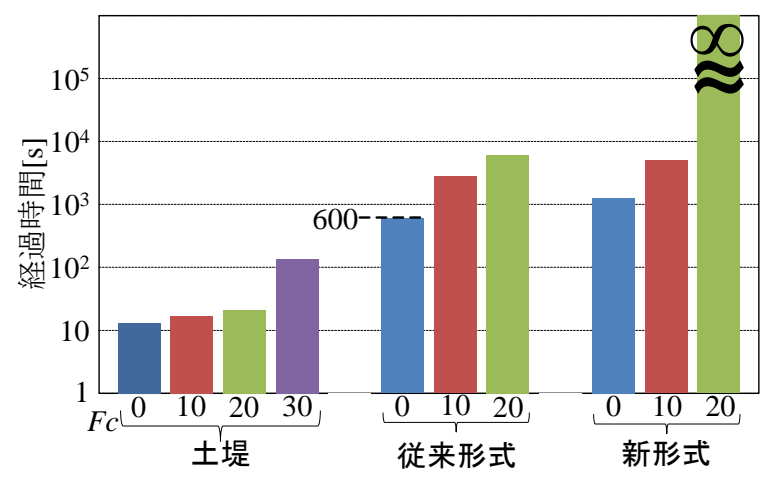

図-11＼cjkstart各実験ケースにおける堤防の欠損時間

いる.このように堤体材料に細粒分を増やすと，従来・ 新形式堤防の耐越流侵食性が飛躍的に向上寸ることが示 唆された.

\section{2) 要因分析}

以上の結果より，従来形式・新形式堤防は，堤体材料 の細粒分含有率の増加とともに而越流侵食性を著しく向 上した. この要因として従来・新形式堤防共通のものは, 
(1) 細粒分混合による移動限界掃流力と粘着力の増加

(2) 堤体内の浸透能低下と裹のり面被覆工の安定化

(3) 堤体材料の吸出し防止

(4) 被覆工と堤体材料間の粘着力の増加

という4点が挙げられる．まず，(1)としては，3. (1)で示 されたように，細粒分含有率を増加させると土堤自体の 侵食が抑制されている．混合粒径となることで砂のみの 単一粒径よりも移動限界掃流力は増加する ${ }^{13)}$. それに加 えて, 細粒分を含む粘性土では, 砂のみの非粘性土と異 なり土粒子間の粘着力の抵抗により ${ }^{22}$ ，堤体表面流から の侵食速度が抑制される. (2)については, 3. (2)で詳述し たように，細粒分を 10，20\%にすると，砂地盤と比べて 透水係数が 1 ケ夕小さくなり, それに伴って表のり面か らの浸潤面が裏のり尻に到達寸る時間が大幅にかかると ともに, 裏のり面自体が浸潤しない. そのため, 裏のり 面上に敷設されている被覆工の不安定化や被覆工間のず れが発生しにくくなる. (3)に関しては, 細粒分が無いケ 一スでは，被覆工と堤体間の隙間ができると，堤体材料 が吸い出されるが, 細粒分を多く含む堤体材料で, かつ, 被覆工で堤体がカバーされていると，上記の(1)と(2)の効 果で堤体材料の吸出しが防止される. (4)では, 細粒分混 合による粘着力増加に伴い, 被覆工と堤体材料間の粘着 性も増加寸る $\left(F c=0 \%\right.$ と 20\%では3 倍の粘着力増加 ${ }^{\left.{ }^{14}\right)}$.

これらの効果により, 新形式・従来形式堤防では, 堤 体表面の被覆工の変位や不陸・隙間の発生, それに伴う 被覆工流出にかかる時間が大幅に伸びて，而越流侵食性 が大幅に向上している. さらに，新形式堤防独自の効果 としては，上の 4 点に加えて,

(5) ジオグリッドによる被覆工の流出抑制

(6) 堤体表面侵食の抑制

により, 従来形式堤防よりも高い而越流侵食性を有する のみならず，一旦不陸が生じても粘り強く壊れにくい構 造を発現できていることが明らかとなった。

\section{4. 結論}

本研究で得られた主な結論は以下のとおりである. (1)細粒分を堤体内に混合させると，土堤，従来形式，新 形式堤防共に堤防の而越流侵食性は大幅に向上寸ること が明らかとなった。

(2) 新形式・従来形式堤防では, 細粒分含有率を増加させ ると, 裏のり面の被覆工や洗掘防止工の流出までの時間 が増加する. これは, 細粒分混合による粘着力の増加, 堤体内の浸透能低下と裏のり面被覆工の安定化, 堤体材 料の吸出し防止効果によるものと考えられる.

(3) 新形式堤防では, ジオグリッドによるパネル流出や堤 体表面侵食の抑制効果が発揮されるので, 不陸が生じて
も粘り強く壊れにくい構造を発現できている.

本実験で得られた結果を実堤防の強化技術として適用 するには，相似則に関する検討を深化させることのみな らず，大型水路を用いた実物大スケール実験を行う必要 があり，今後行う予定である.

謝辞 : 本研究の一部は, 科学研究費補助金・基盤研究 (B) (研究代表者: 二瓶泰雄) によって実施された. また, 本実験を遂行するに当たり, 東京理科大学理工学部土木 工学科水理研究室の学生諸氏には, 多大なご協力を頂い た.ここに記して深甚なる謝意を表します.

\section{参考文献}

1) 土木学会水工学委員会山口・島根水害調查団: 平成 25 年 7 月 28 日山口・島根豪雨災害調查報告（速報版）, http://committees.jsce.or.jphreport/system/files2 201307yamaguchi-shiman e.pdf, 2013.

2) (社)日本河川協会編 : 改訂新版建設省河川砂防技術基淮 (案)同解説 設計編 I ] , pp.3-30，1997.

3) 土木学会 : 水理公式集 [平成 11 年版], 丸善, pp.194205,

4) 吉川勝秀 (編著) : 河川堤防学 新しい河川工学, 技報堂 出版, pp.1-278, 2008.

5) 和田一範 : 地球温暖化に伴う洪水・渴水リスクの評価に関 寸る研究, 地球環境, Vol.11, No.1, pp.67-78, 2006.

6) 福島雅紀, 佐野岳生, 成田秋義, 服部敦 : 航空測量デー夕 等を用いた津波による河川堤防の侵食実態調查, 河川技術 論文集，Vol.18，pp.369-374， 2012.

7）倉上由貴, 二瓶泰雄, 矢田孝次朗, 山崎達也, 山口晋平, 川邊翔平, 菊池喜昭, 龍岡文夫 : 而越流侵食性向上のため の河川堤防補強技術の提案，土木学会論文集 B1（水工学）, Vol.69, No.4, ppI_1219-I_1224, 2013.

8）倉上由貴, 二瓶泰雄, 川邊翔平, 菊池喜昭, 龍岡文夫 : ジ オテキスタイル補強土を用いた而越流侵食河川堤防の提案, ジオシンセティックス論文集，Vol.28，pp.265-272，2013.

9) 柳沢舞美, 二瓶泰雄, 山口晋平, 川邊翔平, 龍岡文夫: 海 岸砂丘と補強盛土技術を組み合わせた新形式防潮堤の提 案, 土木学会論文集 B2 (海岸工学), Vol.59, pp.__886-I_890, 2012.

10) Tatsuoka, F., M, Tateyama, T. Uchimura and J. Koseki: Geosynthetic-reinforced soil retaining walls as important permanent structures, 1996-1997 Mercer Lecture, Geosynthetic International, Vol.4, No.2,pp.81-136, 1997.

11) 福岡捷二:洪水の水理と河道の設計法, 森北出版, pp.185-230, 2005.

12) 関根正人: 移動床流れの水理学, 共立出版, pp.135-143, 2005,

13) Egiazaroff, I.V. : Calculation of Nonuniform Sediment Concentrations, Proc. ASCE, HY 4, 1965.

14）森田麻友, 倉上由貴, 二瓶泰雄 : 小型水路実験に基づく河 川堤防の耐越流侵食性に及ぼす細粒分の影響, 土木学会 年次学術講演会講演概要集第 2 部, Vol.69, pp.353-354, 2014.

(2014. 9.30 受付) 